\title{
Hubungan Kemandirian Belajar, Motivasi Belajar dan Fasilitas Bengkel Pemesinan dengan Hasil Belajar Paket Keahlian Teknik Pemesinan Siswa Kelas Xi di Smk PGRI 2 Jombang
}

\author{
Krisdianto Hadi ${ }^{1)}$, Purnomo ${ }^{2)}$, dan Putut Murdanto ${ }^{3)}$ \\ ${ }^{1,2,3}$ Program Studi S1 Pendidikan Teknik Mesin Jurusan Teknik Mesin \\ ${ }^{1,2,3}$ Fakultas Teknik Universitas Negeri Malang \\ 1,2,3 Jalan Semarang No. 5, Malang 65145 \\ Email: krisdiantohadi1994@gmail.com
}

\begin{abstract}
Abstrak: Tujuan penelitian ini adalah untuk mengetahui hubungan kemandirian belajar, motivasi belajar, dan fasilitas bengkel pemesinan dengan hasil belajar paket keahlian teknik pemesinan. Analisis yang digunakan yakni, kuantitatif deskriptif korelasional. Sampel yang digunakan penelitian ini berjumlah 94 responden. Hipotesis yang diajukan adalah hubungan secara parsial dan simultan antara kemandirian belajar, motivasi belajar, dan fasilitas bengkel pemesinan dengan hasil belajar paket keahlian teknik pemesinan. Hasil pengujian hipotesis (1) uji secara simultan terdapat hubungan yang positif dan signifikan antara kemandirian belajar, motivasi belajar, dan fasilitas bengkel pemesinan dengan hasil belajar paket keahlian teknik pemesinan, (2) secara parsial tidak ada hubungan yang signifikan antara kemandirian belajar dengan hasil belajar paket keahlian teknik pemesinan, (3) ada hubungan yang signifikan antara motivasi belajar dengan hasil belajar paket keahlian teknik pemesinan, (4) ada hubungan yang signifikan antara fasilitas bengkel pemesinan dengan hasil belajar paket keahlian teknik pemesinan.
\end{abstract}

Kata kunci: kemandirian belajar, motivasi belajar, fasilitas bengkel pemesinan, hasil belajar.

\begin{abstract}
The purpose of this research is to know the Relationship between self-learning, learning motivation, workshop facilities and learning achievement of mechanical engineering. The analysis used is the quantitative descriptive correlational. The sample used is 94 respondents. The hypothesis proposed is a partial and simultaneous relationship between Hypothesis proposed is partial and simultaneous relationship between self-learning, learning motivation, workshop facilities and learning achievement of mechanical engineering. Result of hypothesis testing (1) simultaneously, there was a significant relationship between self-learning, learning motivation, workshop facilities and learning achievement of mechanical engineering, (2) partially, there was no significant relationship between the self-learning and learning achievement of mechanical engineering, (3) there was a significant relationship between the learning motivation and learning achievement of mechanical engineering, (4) there was a significant relationship between workshop facilities and learning achievement of mechanical engineering.
\end{abstract}

Key words: self-learning, learning motivation, workshop facilities, learning achievement of mechanical engineering.

Pendidikan di Indonesia saat ini pada tahap berkembang yang memerlukan peningkatan mutu pendidikan agar kualitas pendidikan terus bertambah. Upaya peningkatan mutu pendidikan salah satunya dengan meningkatkan kualitas pembelajaran di dalam kelas dapat berupa perencanaan dan pelaksanaan pembelajaran sesuai dengan kurikulum yang berlaku. Hal tersebut merupakan suatu proses atau usaha manusia untuk membelajarkan peserta didik menuju kedewasaannya. Apabila peserta didik telah mencapai kedewasaannya dalam belajar maka keberhasilanya akan mudah didapat dan mutu pendidikan juga meningkat Telah disebutkan dalam tujuan pendidikan nasional yang tercantum dalam Peraturan Pemerintah (PP) No. 19 tahun 2005 Bab II pasal 4, yaitu "Standart Nasional Pendidikan bertujuan menjamin mutu pendidikan nasional dalam rangka mencerdaskan kehidupan bangsa dan membentuk watak peradaban bangsa yang bermanfaat".

Pendidikan merupakan upaya yang disengaja dengan tujuan membelajarkan peserta didik kepada dunia yang lebih luas melalui proses pembelajaran agar kemampuanya dapat berkembang. Pendidikan dapat juga dikatakan sebagai penghubung antara dua sisi, satu sisi individu yang sedang berkembang dan sisi lain nilai sosial, moral, dan intelektual. Hal tersebut menjadi tugas dan tanggung jawab pendidik untuk mendorong siswa untuk mengembangkan potensinya agar berhasil dalam belajarnya.

Keberhasilan siswa dalam menempuh pendidikan dapat dilihat dari perkembangan proses belajar dan hasil akhir yang diperoleh setelah melalui tahap-tahap evaluasi pembelajaran. Hasil belajar yang diperoleh tersebut dinilai dengan tes dan pengamatan terhadap penguasaan materi setiap kompetensi siswa. Hasil belajar tersebut dilaporkan nilai yang dibukukan dalam bentuk rapor sebagai catatan hasil belajar siswa setelah diuji setiap semester.

Hasil belajar merupakan integral dari proses pembelajaran setelah adanya evaluasi pembelajaran. Semua jenjang pendidikan tidak terlepas dari evaluasi yang menentukan hasil belajar peserta didik dan untuk memperbaiki kedepannya. Siswa 
dikatakan berhasil apabila telah mencapai kriteria ketuntasan minimal (KKM) yang telah ditentukan. Hasil belajar yang tinggi akan mendapatkan kemudahan tentunya untuk modal bekerja dan untuk melanjutkan pendidikan yang lebih tinggi.

Pencapaian hasil belajar peserta didik dipengaruhi oleh beberapa hal yang berkaitan dengan proses pembelajaran. Kompri (2016: 227) menyatakan faktor-faktor yang mempengaruhi belajar siswa:

"Secara garis besar, proses belajar dipengaruhi oleh dua faktor, yaitu faktor internal dan faktor eksternal. Faktor-faktor internal meliputi faktor fisiologis, yaitu jasmani siswa dan psikologis, yaitu kecerdasan atau intelegensi siswa, motivasi, minat, sikap, bakat. Faktor-faktor eksternal meliputi lingkungan alamiah dan lingkungan sosial budaya, sedangkan lingkungan nonsosial atau instrumental, yaitu kurikulum, program, fasilitas belajar, guru. Hasil belajar yang dicapai siswa dipengaruhi oleh dua faktor utama yakni faktor dari dalam diri siswa itu dan faktor yang datang dari luar diri siswa atau faktor lingkungan. Salah satu faktor tersebut adalah metode mengajar guru didalam kelas/sekolah."

Berdasarkan pendapat diatas dapat disimpulkan bahwa keberhasilan siswa dalam belajar dipengaruhi oleh beberapa faktor, yaitu faktor internal yang ada pada siswa, faktor eksternal siswa, dan faktor pendekatan dalam belajar. Faktor internal siswa, yaitu intelegensi, sikap, bakat, minat, motivasi, jasmani siswa, rasa percaya diri, konsentrasi belajar, dan kebiasaan belajar. Faktor eksternal siswa, yaitu lingkungan sosial (keluarga, sekolah, masyarakat, guru dan staf, teman, alam, sarana dan prasarana). Faktor pendekatan belajar, yaitu pendekatan tinggi, pendekatan sedang dan pendekatan rendah.

Fasilitas pembelajaran dapat berpengaruh pada hasil pembelajaran. Fasilitas bengkel pemesinan yang baik dan lengkap dapat mempengaruhi hasil belajar siswa menjadi lebih baik, begitu sebaliknya jika kurang fasilitas bengkel dapat mempengaruhi hasil belajar siswa yang buruk. Fasilitas bengkel bagi SMK merupakan hal yang sangat penting, hal tersebut untuk menunjang proses pembelajaran bagi siswa. Tidak hanya mempelajari teori saja akan tetapi juga melibatkan praktikum bagi siswa.

Selain fasilitas bengkel pemesinan yang mempengaruhi hasil belajar siswa, faktor intrinsik siswa juga dapat mempengaruhi hasil belajar yaitu, motivasi dan kemandirian belajar saling memengaruhi hasil belajar siswa. Motivasi adalah suatu proses diinisiasikannya dan dipertahankannya aktifitas yang diarahkan pada pencapaian tujuan. Motivasi merupakan sebuah proses ketimbang hasil (Schunk dkk, 2012: 6). Motivasi belajar timbul karena ada keinginan untuk berhasil, dorongan untuk kebutuhan belajar, dan mempunnyai harapan kedepannya. Motivasi sebagai daya dorongan dalam diri siswa untuk melakukan proses belajar dan dapat memberikan arahan pada kegiatan pembelajaran yang dapat membantu siswa untuk mencapai tujuan pembelajaran. Berkaitan dengan hasil belajar siswa, motivasi sangat penting dimiliki siswa karena dapat berpengaruh pada hasil belajarnya. Siswa yang memiliki motivasi yang tinggi dalam belajar tentunya mendapat nilai yang tinggi, karena motivasi dapat memicu semangat belajar dan dapat mempengaruhi pada hasil belajar.

Motivasi dalam belajar dibedakan menjadi dua, yaitu motivasi ekstinsik dan intrinsik. Seperti yang diungkapkan oleh Santrock (2011: 204) Motivasi ekstrinsik sering kali dipengaruhi oleh insentif eksternal seperti penghargaan dan hukuman. Motivasi intrinsik adalah motivasi untuk melakukan sesuatu demi hal itu sendiri (sebuah tujuan itu sendiri).

Kemandirian belajar juga dapat mempengaruhi hasil belajar. Tirtarahardja (2008: 50) mengatakan bahwa "kemandirian dalam belajar dapat diartikan sebagai aktifitas belajar yang berlangsungnya lebih didorong oleh kemauan sendiri, pilihan sendiri, dan tanggung jawab sendiri dari pembelajar." Kemandirian merupakan salah satu aspek kepribadian yang sangat penting untuk setiap individu. Individu yang mempunyai kemandirian belajar yang tinggi relatif mampu menyelesaikan permasalahan karena adanya kemandirian dalam dirinya. Individu yang mandiri akan berusaha menghadapi, mengolah, dan menyelesaikan permasalahan yang dihadapinya.

SMK PGRI 2 Jombang adalah sekolah kejuruan yang cukup besar di Kabupaten Jombang. Sekolah ini memiliki 4 jurusan kompetensi keahlian dengan jumlah siswa 999 termasuk didalamnya adalah bidang keahlian terdapat 3 kelas teknik pemesinan (TPM) setiap angkatan per tanggal 5 maret 2017, khusus jurusan teknik pemesinan pada tahun ajaran 2016/2017 untuk kelas XI TPM berjumlah 124 orang (http://dapo.dikdasmen.kemdikbud.go.id/sekolah). Sekolah ini merupakan salah satu sekolah yang menyumbangkan lulusan peserta didik SMK yang cukup besar di Kabupaten Jombang khususnya dibidang teknik pemesinan.

Jurusan teknik pemesinan SMK PGRI 2 Jombang menerapkan pembelajaran dengan berpedoman pada kurikulum 2013 dimana pembelajaran di sekolah melalui mata pelajaran pada paket keahlian teknik pemesinan menggunakan teori dan praktik yang spesifik. Penggunaan mata pelajaran pada paket keahlian teknik pemesinan ini didasarkan pada pembelajaran yang di fokuskan pada peserta didik, agar dapat menunjang kompetensi setiap peserta didik. Sejalan dengan salah satu misi sekolah yaitu "meningkatkan efektifitas dan efisiensi proses pembelajaran dan bimbingan secara maksimal” (www.smkpgri2jombang.com)

Pada 19 Desember 2013 SMK PGRI 2 Jombang juga telah mendapatkan sertifikat sistem penjamin mutu ISO 90001:2008 dari NQA. Kompetensi keahlian teknik pemesinan yang harus dikuasai melalui mata pelajaran peminatan pada paket keahlian teknik pemesinan sesuai dengan spektrum kurikulum 2013 SMK meliputi beberapa aspek yaitu: (1) teknik gambar manufaktur, (2) teknik pemesinan bubut, (3) teknik pemesinan frais, (4) teknik pemesinan gerinda, dan (5) teknik pemesinan Computer Numerical Control (CNC).

Motivasi peserta didik masih rendah hal tersebut dapat berpengaruh pada hasil belajar siswa. Hasil observasi dan wawancara terhadap peserta didik, ditemukan hasil bahwa mereka kurang tekun dan cenderung tidak bersungguh-sungguh untuk mendapatkan nilai yang baik dalam belajar terutama dalam mengerjakan tugas serta bertanggung jawab terhadap tugas yang diberikan. Mayoritas siswa hanya mendengarkan guru tanpa ada timbal balik siswa kepada guru, sedangkan pembelajaran yang baik adalah adanya interaksi dalam bentuk timbal balik, tanggapan, sanggahan, dan tanya jawab oleh guru dan siswa. 
Hal tersebut juga dipengaruhi kemandirian belajar siswa. Kemandirian belajar siswa masih rendah, hal ini terlihat dari kebiasaan belajar siswa. Hasil observasi pada saat pembelajaran berlangsung menunjukkan bahwa siswa kurang aktif dalam kegiatan belajar. Siswa kurang belajar dengan inisiatif sendiri dan memiliki ketergantungan untuk belajar dari guru. Hal ini terlihat ketika guru harus selalu mengingatkan siswa untuk mendengarkan, memperhatikan, dan mencatat materi dari pejelasan guru. Mayoritas siswa belajar ketika guru menyuruh, menekan, menunggui, dan ketika guru mengajukan pertanyaan. Siswa kurang menyadari untuk belajar secara mandiri pada saat tidak ada guru. Hal tersebut jika terus menerus dilakukan oleh siswa dapat berpengaruh pada hasil belajar yang dicapaianya.

Dari beberapa pernyataan di atas dapat disimpulkan bahwa motivasi belajar dan kemandirian belajar dapat mempengaruhi hasil belajar siswa. Pernyataan tersebut sejalan dengan penelitian terdahulu yang menjelaskan bahwa terdapat hubungan antara motivasi belajar, kemandirian belajar dan bimbingan akademik terhadap prestasi belajar mahasiswa di STIKES A. Yani Yogyakarta (Sunarsih, 2014).

Selain motivasi dan kemandirian belajar siswa, terdapat faktor ekstrinsik siswa yang mempengaruhi hasil belajarnya, yakni fasilitas bengkel pemesinan. Hasil observasi yang dilakukan terdapat permasalahan fasilitas bengkel pemesinan yang masih kurang lengkap, yaitu mesin CNC, mesin skrap dan peralatan ruang pengukuran dan pengujian logam, dan area kerja mesin gerinda. Fasilitas bengkel pemesinan ini belum memenuhi standart yang ditetapkan oleh Permendiknas No. 40 Tahun 2008 tentang standart sarana dan prasarana. Di SMK PGRI 2 Jombang dalam fasilitas bengkel pemesinan hanya mempunyai area kerja bangku, area kerja mesin bubut, area kerja mesin frais, ruang penyimpanan dan instruktur. Kurang lengkapnya fasilitas bengkel pemesinan tersebut juga akan mempengaruhi hasil belajar siswa. Pernyataan tersebut sejalan dengan penelitian terdahulu yang menjelaskan bahwa terdapat hubungan yang signifikan antara fasilitas bengkel pemesinan, pemahaman dan penerapan K3 dengan hasil belajar praktikum pemesinan siswa kelas XI di SMK Islam 1 Blitar (Setiawan, 2013: 79).

Penelitian tentang hubungan kemandirian belajar, motivasi belajar, dan fasilitas bengkel pemesinan dengan hasil belajar siswa SMK PGRI 2 Jombang belum pernah dilakukan sebelumnya, sehingga tidak ada data empirik yang menyatakan ada tidaknya hubungan aspek tersebut. Penelitian ini perlu dilakukan guna memberikan gambaran dan pertimbangan bagi seluruh stake holder di sekolah khususnya dalam mengembangkan program pembelajaran untuk mendidik dan menumbuhkan motivasi dan kemandirian belajar serta mengembangkan fasilitas bengkel pemesinan untuk kebutuhan praktikum siswa. Berdasarkan uraian diatas maka perlu dilakukan penelitian dengan judul "Hubungan Kemandirian Belajar, Motivasi Belajar, dan Fasilitas Bengkel Pemesinan dengan Hasil Belajar Paket Keahlian Teknik Pemesinan Siswa Kelas XI di SMK PGRI 2 Jombang.”

\section{METODE}

Penelitian ini menggunakan pendekatan kuantitatif. Dikatakan pendekatan kuantitatif karena menggunakan jenis desain penelitian Ex Post Facto dan data penelitian nantinya berupa angka untuk dilakukan analisis secara statistik. Penelitian ini juga dapat dikatakan penelitian korelasional. Penelitian korelasional ditujukan untuk mengetahui hubungan suatu variabel dengan variabel-variabel yang lain (Sukmadinata, 2013: 56).

Adapun rancangan penelitian adalah sebagai berikut:

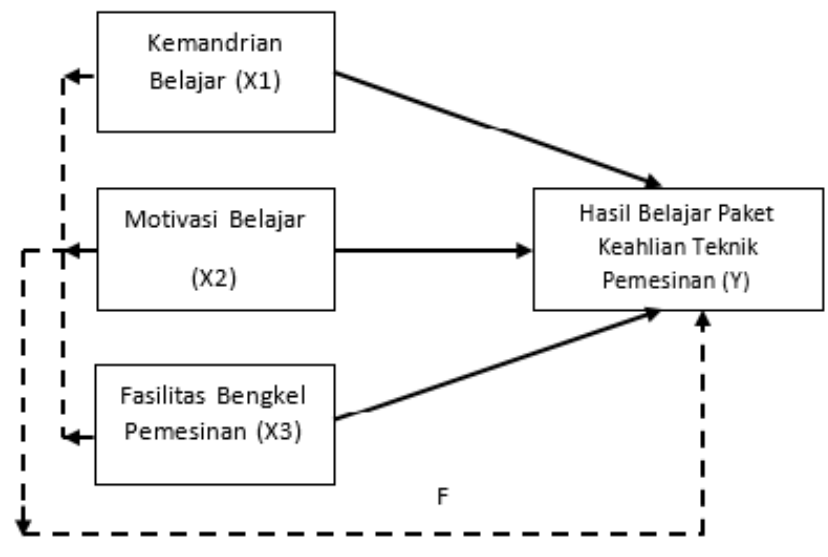

Populasi dalam penelitian ini adalah siswa kelas XI Teknik Pemesinan SMK PGRI 2 Jombang. Pengambilan sampel ini menggunakan teknik proporsional random sampling. Dalam penelitian ini diambil 94 siswa sebagai sampel. Instrumen yang digunakan dalam penelitian ini adalah menggunakan kuisioner (angket), observasi dan studi dokumentasi. Pengujian hipotesis yang digunakan adalah analisis regresi berganda untuk untuk uji hipotesis secara simultan dan analisis korelasi parsial untuk uji hipotesis secara parsial. 


\section{HASIL}

Berdasarkan analisis deskriptif yang sudah dilakukan pada variabel kemandirian belajar adalah 18 siswa (19,14\%) mempunyai kemandirian belajar yang sangat tinggi, 40 siswa (42,55\%) mempunyai kemandirian belajar yang tinggi, 19 siswa $(20,21 \%)$ mempunyai kemandirian belajar yang sedang, dan 17 siswa $(18,08 \%)$ mempunyai kemandirian belajar rendah. Pada variabel motivasi belajar, yaitu 28 siswa $(29,78 \%)$ mempunyai motivasi belajar yang sangat tinggi, 30 siswa $(31,91 \%)$ mempunyai motivasi belajar yang tinggi, 26 siswa $(27,65 \%)$ mempunyai motivasi belajar yang sedang, dan 10 siswa $(10,63 \%)$ mempunyai motivasi belajar yang rendah.

Pada varriabel fasilitas bengkel pemesinan, yaitu 34 siswa $(36,17 \%)$ menjawab bahwa fasilitas bengkel pemesinan dalam kondisi sangat baik, 32 siswa (34,04\%) menjawab bahwa fasilitas bengkel pemesinan dalam kondisi baik, 12 siswa (12,76\%) menjawab bahwa fasilitas bengkel pemesinan dalam kondisi sedang, dan 16 siswa $(17,02 \%)$ menjawab bahwa fasilitas bengkel pemesinan dalam kondisi kurang baik. Pada variabel hasil belajar paket keahlian teknik pemesinan, yaitu 20 siswa (21,27\%) mendapatkan nilai paket keahlian teknik pemesinan baik, dan 74 siswa $(78,72 \%)$ mendapatkan nilai paket keahlian teknik pemesinan cukup.

Berdasarkan hasil pengujian hipotesis pertama mengenai hubungan kemandirian belajar, motivasi belajar, dan fasilitas bengkel pemesinan dengan hasil belajar paket keahlian teknik pemesinan diketahui bahwa nilai signifikansi $0,000<0,05$ maka Ho ditolak dan Ha diterima. Artinya ada hubungan yang signifikan antara ketiga variabel bebas Kemandirian Belajar $\left(\mathrm{X}_{1}\right)$, Motivasi Belajar $\left(\mathrm{X}_{2}\right)$, Fasilitas Bengkel Pemesinan $\left(\mathrm{X}_{3}\right)$ secara bersama-sama dengan variabel terikat Hasil Belajar Praktikum Pemesinan (Y).

Berdasarkan hasil pengujian hipotesis kedua mengenai hubungan secara parsial antara kemandirian belajar dengan hasil belajar paket keahlian teknik pemesinan diketahui bahwa nilai signifikansi p sebesar 0,179>0,05, maka Ha ditolak dan Ha diterima. Artinya tidak ada hubungan yang signifikan antara variabel kemandirian belajar $\left(\mathrm{X}_{1}\right)$ dengan hasil belajar paket keahlian teknik pemesinan (Y). Koefisien Correlation Partial yang didapatkan yaitu sebesar 0,141 (positif), artinya semakin baik kemandirian belajar maka semakin baik pula hasil belajar paket keahlian teknik pemesinan.

Berdasarkan pengujian hipotesis ketiga mengenai hubungan motivasi belajar dengan hasil belajar paket keahlian teknik pemesinan diketahui bahwa nilai signifikansi p sebesar $0,030<0,05$, maka Ho ditolak dan Ha diterima. Artinya ada hubungan yang signifikan antara variabel motivasi belajar $\left(\mathrm{X}_{2}\right)$ dengan hasil belajar paket keahlian teknik pemesinan (Y). Koefisien Correlation Partial yang didapatkan yaitu sebesar 0,226 (positif), artinya semakin baik motivasi belajar maka semakin baik pula hasil belajar paket keahlian teknik pemesinan.

Berdasarkan pengujian hipotesis ketiga mengenai hubungan motivasi belajar dengan hasil belajar paket keahlian teknik pemesinan diketahui bahwa nilai signifikansi p sebesar $0,011<0,05$, maka Ho ditolak dan Ha diterima. Artinya ada hubungan yang signifikan antara variabel fasilitas bengkel pemesinan $\left(\mathrm{X}_{3}\right)$ dengan hasil belajar paket keahlian teknik pemesinan ( $\mathrm{Y}$ ). Koefisien Correlation Partial yang didapatkan yaitu sebesar 0,263 (positif), artinya semakin baik fasilitas bengkel pemesinan maka semakin baik pula hasil belajar paket keahlian teknik pemesinan.

\section{PEMBAHASAN}

Berdasarkan hasil penelitian analisis data deskriptif pada variabel kemandirian belajar dapat disimpulkan bahwa kemandirian belajar siswa dalam belajar yang telah dijelaskan diatas dapat disimpulkan bahwa kemandirian belajar siswa tergolong tinggi. Variabel motivasi belajar, yaitu motivasi belajar siswa dalam belajar yang telah dijelaskan diatas dapat disimpulkan bahwa motivasi belajar siswa tergolong tinggi.

Pada variabel fasilitas bengkel pemesinan yaitu bahwa fasilitas bengkel pemesinan yang ada di SMK PGRI 2 Jombang dalam kondisi baik dan variabel hasil belajar paket keahlian teknik pemesinan siswa yang telah dijelaskan diatas dapat disimpulkan bahwa hasil belajar siswa tergolong cukup.

Pengujian hipotesis pertama menyatakan ada hubungan yang signifikan antara kemandirian belajar, motivasi belajar, dan fasilitas bengkel pemesinan secara bersama-sama dengan hasil belajar paket keahlian teknik pemesinan. Pengujian secara parsial menunjukkan bahwa variabel kemandirian belajar tidak memiliki hubungan yang signifikan dengan hasil belajar paket keahlian teknik pemesinan. Pengujian secara parsial pada variabel motivasi belajar dan fasilitas bengkel pemesinan masing-masing memiliki hubungan yang signifikan dengan hasil belajar paket keahlian teknik pemesinan.

Pada pengujian hipotesis kedua menyatakan bahwa variabel kemandirian belajar tidak memiliki hubungan yang signifikan dengan hasil belajar paket keahlian teknik pemesinan. Hasil penelitian yang di dapatkan diatas juga didukung dengan penelitian sebelumnya yang dilakukan oleh Wulandari (2014) dengan judul "Hubungan antara lingkungan belajar, kemandirian belajar, motivasi belajar dan prestasi belajar siswa pada mata pelajaran akuntansi studi kasus pada siswa kelas XII SMA Pangundi Luhur St. Louis IX Sedayu Yogyakarta.” Hasil dari penelitian tersebut adalah tidak ada hubungan yang positif dan signifikan antara kemandirian belajar dan prestasi belajar siswa. Pengujian secara parsial pada variabel motivasi belajar dan fasilitas bengkel pemesinan masing-masing memiliki hubungan yang signifikan dengan hasil belajar paket keahlian teknik pemesinan.

Hasil penelitian yang di dapatkan diatas juga didukung dengan penelitian sebelumnya yang dilakukan oleh Penelitian Wibowo (2009) dengan judul "Hubungan bakat mekanik, motivasi belajar, dan persepsi siswa tentang keterampilan mengajar 
guru dengan prestasi belajar service engine siswa SMK program keahlian mekanik otomotif." Hasil dari penelitian tersebut adalah motivasi belajar berkorelasi positif dengan pestasi belajar service engine siswa SMK program keahlian mekanik otomotif.

Penelitian Setiawan (2013) dengan judul "Hubungan fasilitas bengkel pemesinan, pemahaman dan penerapan K3 dengan hasil belajar praktikum pemesinan siswa kelas XI di SMK Islam 1 Blitar." Hasil dari penelitian tersebut adalah terdapat hubungan positif dan signifikan antara fasilitas bengkel pemesinan dengan hasil belajar praktikum pemesinan siswa kelas XI di SMK Islam 1 Blitar.

\section{Simpulan}

\section{SIMPULAN DAN SARAN}

Penelitian ini dapat disimpulkan bahwa : (1) kemandirian belajar dan motivasi belajar siswa tergolong tinggi, fasilitas bengkel pemesinan tergolong sangat tinggi, dan hasil belajar siswa tergolong cukup, (2) ada hubungan yang signifikan antara ketiga variabel bebas Kemandirian Belajar $\left(\mathrm{X}_{1}\right)$, Motivasi Belajar $\left(\mathrm{X}_{2}\right)$, Fasilitas Bengkel Pemesinan $\left(\mathrm{X}_{3}\right)$ secara bersama-sama dengan variabel terikat Hasil Belajar Praktikum Pemesinan (Y), (3) tidak ada hubungan yang signifikan antara variabel kemandirian belajar $\left(\mathrm{X}_{1}\right)$ dengan hasil belajar paket keahlian teknik pemesinan $(\mathrm{Y})$, (4) ada hubungan yang signifikan antara variabel motivasi belajar $\left(\mathrm{X}_{2}\right)$ dengan hasil belajar paket keahlian teknik pemesinan $(\mathrm{Y})$, dan (5) ada hubungan yang signifikan antara variabel fasilitas bengkel pemesinan $\left(\mathrm{X}_{3}\right)$ dengan hasil belajar paket keahlian teknik pemesinan $(\mathrm{Y})$.

\section{Saran}

Berdasarkan hasil penelitian tersebut, pihak SMK PGRI 2 Jombang bisa manjadikan penelitian ini sebagai acuan untuk dapat melengkapi kekurangan fasilitas bengkel pemesinan tersebut sesuai dengan standart yang ditetapkan oleh permendiknas. Bagi guru, kemandirian dan motivasi belajar siswa tergolong tinggi, akan tetapi terdapat beberapa siswa yang mempunyai kemandirian dan motivasi belajar rendah.bapak ibu guru bisa menjadikan penelitian ini sebagai informasi untuk memotivasi siswa agar prestasi belajarnya juga meningkat.

\section{DAFTAR RUJUKAN}

Departemen Pendidikan Nasional, 2005. Peraturan Pemerintah Nomor 19 Tahun 2005, tentang Standart Nasional Pendidikan. Jakarta: Depdiknas.

Kompri, 2016. Motivasi Pembelajaran Perspektif Guru dan Siswa. Bandung: PT Remaja Rosdakarya.

Schunk, Dale H, Pintrich Paul R, \& Meece Judith L. 2012. Motivasi dalam Pendidikan Teori, Penelitian dan Aplikasi. Jakarta: PT INDEKS.

Santrock, Jhon W. 2011. Psikologi Pendidikan, edisi 3 buku 2. Jakarta: Salemba Humanika.

Tirtarahardja U. \& S.L La Sulo. 2008. Pengantar Pendidikan. Jakarta: PT Rineka Cipta.

Sunarsih, Tri. Hubungan Antara Motivasi Belajar, Kemandirian Belajar dan Bimbingan Akademik Terhadap Prestasi Belajar Mahasiswa Di Stikes A. Yani Yogyakarta. 2009. (Online) (http://eprints.uns.ac.id/2537/1/134420808201008111.pdf). Diakses 7 April 2017.

Direktorat Jendral Pendidikan Dasar dan Menengah Kementrian Pendidikan dan Kebudayaan. Data Pokok Pendidikan Dasar dan Menengah. (Online). (http://dapo.dikdasmen.kemdikbud.go.id/sekolah/8263B3DEF76C59A1DDF9). Diakses 9 Maret 2017.

Sukmadinata, Nana Syaodih. 2013. Metode Penelitian Pendidikan. Bandung: PT Remaja Rosdakarya.

Wibowo, Sigit W. 2009. Hubungan Bakat Mekanik, Mtivasi Belajar, dan Persepsi Siswa Tentang Ketrampilan Mengajar Guru dengan Prestasi Belajar Service Engine Siswa Smk Program Keahlian Mekanik Otomotif. (Online). (http://journal.um.ac.id/index.php/teknologikejuruan/article/view/3075/435). Diakses 7 April 2017.

Setiawan, Deny. 2013. Hubungan Fasilitas Bengkel Pemesinan, Pemahaman dan Penerapan K3 dengan Hasil Belajar Praktikum Pemesinan Siswa Kelas XI di SMK Islam 1 Blitar. Skripsi Tidak di Terbitkan. Malang: Fakultas Teknik UM.

Wulandari, Puspa. 2014. Hubungan antara lingkungan belajar, kemandirian belajar, motivasi belajar dan prestasi belajar siswa pada mata pelajaran akuntansi studi kasus pada siswa kelas XII SMA Pangundi Luhur St. Louis IX Sedayu Yogyakarta. (Online). https://repository.usd.ac.id/2107/2/091334061_full.pdf. Diakses 10 Agustus 2017.

Peraturan Menteri Pendidikan Nasional Republik Indonesia No. 40 tahun 2008 tentang Standar Sarana Dan Prasarana Sekolah Menengah Kejuruan/Madrasah Aliyah Kejuruan (SMK/MAK). Jakarta: Direktorat Pembinaan Sekolah Menengah Atas. 